\title{
Teaching African American Religious Pluralism
}

\author{
Monica A. Coleman
}

\begin{abstract}
This chapter reflects on my pedagogical interrogation of classical theories of religious pluralism in light of African American cultural experiences. How does the African American cultural context change the questions posed in theories of religious pluralism? How do people navigate the contemporary manifestations of the diverse religious inputs that make up African American Christianity? What common themes, if any, persist across religious difference because of the historical, cultural and political particularity of African American experiences? I explored these questions while teaching graduate level courses in theological education at Claremont School of Theology. Across two different courses, I focused on lived experience and non-academic religious texts. This involved assigning memoirs and inspirational texts intended for practitioners, arranging site visits and hosting religious leaders as speakers. I sought theoretical propositions across various academic disciplines, and, at times, from massmarket anthologies. I ensured that the course material was relevant for all students. In these courses, students and I learned three things about African American religions relevant for the enterprise of religious pluralism: African American religiosity itself is religiously plural; African American life offers both tools and gifts for living across religious boundaries; and African American religiosity signals the markers of African American culture and politics. Investigating African American religious pluralism also serves to broaden the intellectual enterprise of religious pluralism by reconstructing its primary questions into investigations of how individuals and communities straddle and merge religious differences.
\end{abstract}

\section{Introduction}

I long suspected that classical theories of religious pluralism did not and could not account for African American religiosity. I took these suspicions to the classroom so that my students and I could explore the ways in which African American contexts alter conversations about religious pluralism. In this essay I will share how I developed two courses in African American religious diversity

(C) MONICA A. COLEMAN, 2020 | DOI:10.1163/9789004420045_003

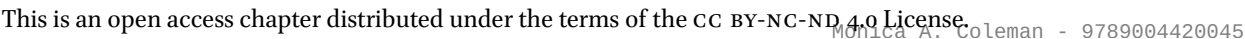


at Claremont School of Theology, focusing on the importance of leading with religious experience, drawing from textual sources outside of the field of academic religion, and establishing relevance for non-black students.

As a kind of prolegomena, I want to share my two early entrées into this conversation. During the first year of my doctoral program at Claremont Graduate University, I took a course on religious pluralism taught by David Ray Griffin. He was working through ideas for the book that eventually became Deep Religious Pluralism. ${ }^{1}$ We read several classic theories of religious pluralism, but for my final paper, I was interested in the following anonymous letter to the editor published in the popular black women's magazine, Essence: "My family still celebrates the holidays in a big way, but I've converted to Yoruba. How can I respect my family's beliefs and still honor my own religion?"2 I saw this brief letter as an example of what might have happened in African American cultures as the 1970s black arts movement coalesced with the Immigration and Nationality Act of 1965 and Cuban immigration to New York City spawned a significant revival of traditional Yoruba religious practices (including Santeria, Lukumi and Ifa) among descendants of the U.S. slavery system. ${ }^{3}$ This anonymous writer's concern about respecting her family's beliefs also reflects the strong role that family plays in African American identity. Without having a language for it, I suspected that individuals from high-context cultures have an interconnected sense of community and self that turns religious differences within families into identity crises. ${ }^{4}$ To put it more positively, the strong connections of family and community of high-context cultures may function as an incentive for developing practices of interreligious understanding.

At the time, I attempted to map John Cobb's theory of mutual transformation onto the way in which I imagined the contemporary encounter between black Protestant Christianity and traditional West African-derived religions takes place. ${ }^{5}$ In this theory, Cobb suggests that the encounter between two religions changes not just the practitioners of different religions, but the religions themselves. Based on the way Cobb writes of a "Buddhized Christianity"

1 David Ray Griffin, ed., Deep Religious Pluralism (Louisville, KY: Westminster John Knox, 2005).

2 Anonymous, Letter to the Editor, Essence (November 2000): 98.

3 Cf. Tracey E. Hucks, Yoruba Traditions and African American Religious Nationalism (Albuquerque, NM: University of New Mexico Press: 2014); and Anthony B. Pinn, "Ashe! Santeria, Orisha-Voodoo and Oyotunji Village," in Varieties of African American Religious Experience (Minneapolis, MN: Fortress, 1998): 53-103.

4 Edward T. Hall, The Silent Language, 1959 (New York: Anchor Books, 1973).

5 John B. Cobb, Beyond Dialogue: Toward a Mutual Transformation of Christianity and Buddhism (Eugene, OR: Wipf and Stock, 1998). 
and a "Christianized Buddhism," I imagined that interaction between Yoruba and Christianity might likewise produce a Yorubized Christianity and a Christianized Yoruba.

Both Griffin and I knew the paper was flawed; the theory was applied optimistically and was slippery, even at its best moments. Griffin encouraged me to keep thinking about the issue because he was certain that I was onto something. I could not then find a language to articulate that there was more at stake than theology and truth claims: that cultural pride and migration greatly influence the ways in which African Americans experience religious differences. That is, during the 196os and 1970s, the civil rights, black power and black aesthetics movements in U.S. politics had a corollary within African American religiosity, with many African Americans converting to religions they felt had a stronger alignment with Pan-African politics and cultural pride - such as the Nation of Islam, Sunni Islam and traditional African religions. Thus a kind of religious pluralism arose within African American communities which was connected to an affirmative act of identity formation and preservation, just as much as - if not more than - a shift in theological understanding. I found none of these intimations in the thinkers I had been assigned in class.

Years later, in my first teaching position at Bennett College for Women in Greensboro, North Carolina, I taught an undergraduate course on African American religious history. All of my students were African American women, many with roots in the southeastern United States. For most of my students, the presence of women in ministry and non-denominational black megachurch culture were normative religious experiences. I assigned Albert Raboteau's canonical work, Slave Religion, over the course of three weeks. ${ }^{6}$ At one point, referring to the lessons about how the religions of the Fon and Dahomey of West Africa syncretized with Catholicism in Haiti and many parts of Louisiana, a student asked me: "How many people practice Vodun?" My immediate response was rather flippant: "No one really knows, because they all go to Catholic mass." As soon as I said this, I realized that teaching African American religions requires teaching religious pluralism in distinctive ways. Rather than exploring how individuals and communities negotiate religious differences, African American religious studies requires discussions about how individuals and communities live across and within religious differences.

These two experiences are touchstones for me as I interrogate classic theories of religious pluralism and African American religious thought. How does

6 Albert J. Raboteau, Slave Religion: The "Invisible Institution" in the Antebellum South (New York: Oxford University Press, 1978). 
the African American cultural context change the questions posed in theories of religious pluralism? How do people navigate the contemporary manifestations of the diverse religious inputs that make up African American Christianity? What common themes, if any, persist across religious difference because of the historical, cultural and political particularity of African American experiences? I explored these concepts in graduate level courses in theological education as a professor at Claremont School of Theology (CST).

During my time at CST, the mission to educate across religious traditions was both distinctive and explicit. I was hired in 2008 when a new institutional mission statement was adopted: "An ecumenical and interfaith institution, Claremont School of Theology seeks to instill students with the ethical integrity, religious intelligence, and intercultural understanding necessary to become effective in thought and action as spiritual leaders in the increasingly diverse, multi-faith world of the 21st century." All students understand that the institution affirms the inherent value in various religious traditions, and most courses incorporate religious plurality in instruction. As an institution that housed leading theorists of religious pluralism, John Hick and John B. Cobb Jr., there were already classes on theories of such pluralism.

My training in theories of religious pluralism had presented religious plurality as a theological problem for those Christians who believe that adherence to certain beliefs about Jesus constitutes the exclusive means of salvation. I learned that there are three primary responses to this problem: exclusivism, inclusivism and pluralism. Deriving from the colonial missionary encounters between Christians (usually Catholics) and non-Christian communities in the two-thirds world, the pluralist approach seeks to understand how nonChristian people who seem good and true might not be denied the Christian promise of salvation. Moving beyond Karl Rahner's description of "anonymous Christians," theories of religious pluralism articulate how religious traditions with competing truth claims and different ideas about God (if theistic at all) might respect one another, dwell together peaceably, seek to understand rather than convert one another, and even learn from and be transformed by one another. Within this tradition, I read the works of John Hick, Paul Knitter, Wilfred Cantwell Smith, John B. Cobb, S. Mark Heim, Diana Eck and David Ray Griffin.

These different thinkers (and many others) look at the major tenets of different religions, compare and contrast them, find resonances in similar philosophical systems, argue for the validity of different starting points or different ends, and share a vision or labor for the common good. I didn't disagree with these perspectives and noted their strengths and weaknesses, as have many friendly critics. This genealogy of scholarship does suggest that mainly white Christian men care about religious pluralism, but the aforementioned letter to 
Essence indicates that is not the case. In all of these writings, there is complete disregard — and sometimes dismissal — of any religious tradition outside of an imperial Christian, Islam, Judaism, Buddhism and Hinduism. I knew that something important was missing.

I wanted to examine the role of culture in studying religious pluralism, with the sense that I might discover something different from that found in the existing theories. In the fall of 2010, I proposed a course with broad parameters: "Religious Pluralism in Cultural Context." Although I intended to explore African American culture, I imagined that other faculty members could use the same course number to explore other cultural contexts. I wrote the course description thusly:

Major theories of religious pluralism emerged from a Western Christian philosophical desire to understand how non-Christian religions related to Christian doctrines of salvation and election. The experience of religious plurality in contemporary society rarely matches up with the classical theories. This is further complicated by cultural diversity. This course discusses the way culture interacts with religious identity to raise issues of syncretism, multiple religious belonging, trans-religious spirituality and pragmatic ethics. We will consider religious experiences in the cultural context through narrative, memoir, motivational literature, interviews, and/or site visits.

\section{$2 \quad$ Lived Experience}

I began with a focus on lived experience. I am trained as a liberation theologian with roots in black and womanist theologies. I am also trained as a process philosopher of religion, a philosophy that has deep connections with the British empirical tradition. Both of these fields start with experience before moving to theory or theological reflection. In fact, any theorizing is to be based on and tested by experience in the world. Because I sensed that existing theories of religious pluralism could not account for African American religious pluralities, I needed to place the lived experience of practitioners before theory so that theory could be examined and assessed in light of the lives of those most affected. ${ }^{7}$

7 Cf. Catherine Albanese, America: Religions and Religion (Belmont, CA: Wadsworth, 2006); Nancy T. Ammerman, Everyday Religion: Observing Modern Religious Lives (New York: Oxford University Press, 2007); Meredith B. McGuire, Lived Religion: Faith and Practice in Everyday Life (New York: Oxford University Press, 2008). 
I facilitated religious experience in three modes: memoirs, guest speakers and site visits. I wanted to look at spiritual writings by African Americans who were explicitly not Christian. I used Alice Walker's essay, in which she describes her pagan identity as the appropriate response to black experience. The essay is titled, "The Only Reason You Want to Go to Heaven Is That You Have Been Driven Out of Your Mind (Off Your Land and Out of Your Lover's Arms): Clear Seeing Inherited Religion and Claiming the Pagan Self," and is the first chapter of her book, Anything We Love Can Be Saved. ${ }^{8}$ I also used memoirs and books that were a combination of self-help/inspiration and memoir. Jan Willis' memoir, Dreaming Me, is well-known among black Buddhists, while books by black New Thought leaders Deborah L. Johnson and Michael Bernard Beckwith and Iyanla Vanzant fit into the latter category. ${ }^{9}$

Assigning these works serves multiple pedagogical and theoretical functions. I hold that non-theologians construct theology, and that religion lives outside of sacred texts. Womanist theology has long affirmed the exploration of black women's literature for theological insight and religious ethics. I follow in that tradition by looking beyond academic scholarship to narrative depictions of African American lives and ideas. As these texts are themselves sacred sources of information, I refute the idea that scholarship in religious pluralism is best done in the side-by-side comparison of canonical texts. These alternative texts both remind us that some religious traditions do not center on written texts, and that the canon of sacred texts is ever expanding. ${ }^{10}$

The choice of these authors and books also highlights the complexity of non-Christian African American spirituality. Walker identifies as pagan in the essay I selected, but in later essays, she discusses how the work of Buddhist

8 Alice Walker, "The Only Reason You Want to Go to Heaven Is That You Have Been Driven Out of Your Mind (Off Your Land and Out of Your Lover's Arms): Clear Seeing Inherited Religion and Claiming the Pagan Self," in Anything We Love Can Be Saved: A Writer's Activism, (New York: Ballatine, 1997), 1-28.

9 Michael Bernard Beckwith, Spiritual Liberation: Fulfilling Your Soul's Potential (New York: Atria Books, 2009); Deborah L. Johnson, The Sacred Yes: Letters from the Infinite (Boulder, CO: Sounds True, 2006); Iyanla Vanzant, Tapping the Power Within: a Path to Self-Empowerment for Women (Carlsbad, CA: Hay House, 1998, 2009).

10 As one example, Tracey Hucks writes about how many practitioners of Ifa (traditional Yoruba religion) learn about their faith from the academic writings of anthropologists and art historians. This does not negate the presence of an Ifa scripture, but the scripture - the Odu — is an oral scripture, which is not fully transcribed, and plays a larger role in lineages of Ifa than in others (where Orisha worship might be primary). Hucks, Yoruba Traditions and African American Religious Nationalism. 
Pema Chodron affects her spirituality. ${ }^{11}$ Willis' book Dreaming Me has a different subtitle in each of its later editions: from "An African-American Woman's Buddhist Journey" to "An African American Woman's Spiritual Journey" to "Black, Baptist and Buddhist - One Woman' Spiritual Journey." Variously emphasizing race, gender and conversion, Willis offers a complex understanding of her own journey. Likewise, there are two significant different editions of Vanzant's Tapping the Power Within. In the first edition, she describes herself as a Yoruba priestess writing for black women's spiritual health. The book outlines Yoruba rituals made palatable for a non-Christian adherent. Twenty years later, Vanzant draws more from her experience as a New Thought Unity minister and emphasizes the relevance of these teachings for the edification of all women. (African rituals are edited out or offered as optional resources.) We also read online articles and interviews with Ann Holmes Redding, an African American Episcopal priest and New Testament scholar best known for how her Episcopal bishop rescinded her ordination after she publicly took shahada, the Muslim confession of faith. It quickly became apparent that many nonChristian African Americans straddle the boundaries of religious difference.

This African American straddling of religious difference raises completely new questions about the classic theories of religious pluralism. An unspoken assumption of those theories is that we each, individually or communally, stand firmly in one religious tradition and interact with others, who squarely occupy another religious tradition. Yet these non-Christian African American writers openly live quite differently. Some religious writers claim two religious traditions without ceding adherence to one or the other. Other religious writers - like those in New Thought traditions - feel they have found a path that is valid for many traditions: their home tradition and other religions as well. The boundaries that classic theories of religious pluralism assume became blurred from the very beginning of my class assignments.

As a second approach to beginning with experience, I invited African American religious leaders who live across religious difference to come to campus and share their spiritual journeys. I invited Ann Holmes Redding, Michael Bernard Beckwith, spiritual director of the ten thousand-member Agape International Spiritual Center in the greater Los Angeles area, and Jeff Obafemi Carr, an ordained Baptist minister based in Nashville, Tennessee, who has been initiated into traditional Yoruba religion. Each speaker gave a public lecture (which was recorded and archived in the school library and online) and then spoke

11 Cf. Buddhist-Christian Studies 32, no. 1 (2012), a special issue on womanism and Buddhism. 
more intimately with the students in my class. My emphasis on experiencing African American plurality outside of sacred texts rendered it important to learn from speakers face-to-face. That is, many of these African American religious experiences are centered in an embodied practice, and so I wanted to continue to learn from those physically and epistemically embodied before us. Personal interaction with speakers also allowed for dialogical learning through question and answer, the natural flow of conversation and extrapolation from unprepared comments.

Conversations with the speakers illuminated the particularity of the African American cultural context. Redding discussed her roots in the African Methodist Episcopal Zion (AMEZ) church where a common call to Eucharist uses the words: "Let us break bread together on our knees/ Let us break bread together on our knees/ When I fall on my knees, with my face to the rising sun, oh Lord, have mercy on me."12 She believes that this song, used for a distinctively Christian act, holds within it the practice of her enslaved Muslim forbears who prayed to the east, "the rising sun." For Redding, being Muslim and Christian is in keeping with African American historical practice. Carr noted that navigating religious difference is no more complex than being black in the United States, and navigating one identity as black and another as American. Beckwith talked about how he tries to bring the best of the black spiritualist and protest traditions in which he was raised to New Thought religion. This merger manifests in principles of "Sacred Service" social justice work and worship music, both of which are innovations in American New Thought religious communities.

The speakers offered three important insights into African American religious pluralism. First, African American religiosity itself is religiously plural. Enslaved Africans were not devoid of religion, but rather brought with them their experiences in Islam ${ }^{13}$ and traditional African religions. These religious experiences encountered an evangelical Protestant Christianity or Catholicism and were variously retained as minority religions or merged with Christianity in ways that created something new, although the contributing religions were still visible. The latter practice is often referred to as "syncretism." While scholars of African American culture debate the extent to which previous religious and cultural traditions are retained and viable in African American

12 "Let Us Break Bread," African American Spiritual. First published in 1925 in The Journal of American Folklore and Saint Helena Island Spirituals, with roots in Gullah/ Geechee slave culture in the Sea Coast islands and coastal area of South Carolina and Georgia.

13 Cf. Richard Brent Turner, "African Muslim Slaves and Islam in Antebellum America," The Cambridge Companion to American Islam, ed., Juliane Hammer and Omid Safi (New York: Cambridge University Press, 2013), 28-44. 
realities, they agree about the central role of history, geography, and slavery in the formation of African American religions. ${ }^{14}$

Second, the speakers suggested that African American life offers tools and gifts for living across religious boundaries. African Americans have long negotiated cultural complexity in the United States (and the Americas), a complexity that includes shifting understandings of race and color and a complex understanding of identity, and this within a larger, and often oppressive, environment. Many African Americans have thus developed the skill sets to maintain multiple religious identities without contradiction in similar ways.

Third, African American religiosity also manifests the markers of African American culture and politics. From their early beginnings in the hush arbors of slavery, African American religions functioned as sources for societal uplift, social contact and political activism..$^{15}$ Sometimes these sources are expressed overtly in preaching and organization; other times more covertly in spiritual songs and charismatic worship. The speakers suggested that these features are not just hallmarks of African American Christianities, but are indeed present in African American non-Christian religions as well. African American culture and politics may contain some elements that can exist in whatever religious tradition African Americans maintain. There are elements of African American intellectual thought and politics that appear in African American religions, and the wrestling and varied forms of reconciliation may indeed be the commonality amidst the theological and experiential differences.

As the third aspect of beginning with experience, my students and I made an early-morning site visit to a worship service at Agape Spiritual Center, an hour's drive from campus. Students arranged their own transport, and I took them to breakfast after a 6:15 a.m. service. This outing allowed students to witness the public teaching and community they had read of and heard about from Michael Beckwith. The site visit allowed us to move from a focus on individual experiences into the experience of a community that lives across religious boundaries. ${ }^{16}$ We heard preaching and music that affirms the religious figures of various religious traditions within a large community that accepts these teachings. From attending a large multi-racial house of worship with

\footnotetext{
14 The classic debate is crystallized by anthropologist Melville K. Herskovkits Myth of a Negro Past, 1941 (Boston: Beacon Press, 1990) and sociologist E. Franklin Frazier Negro Church in America, 1963 (New York: Schocken, 1974).

15 Cf. Raboteau's Slave Religion and C. Eric Lincoln and Lawrence H. Mamiya, The Church in African American Experience (Durham, NC: Duke University Press, 1990).

16 At the time, the Agape website explicitly referred to itself as "transreligious spirituality." The website has since been edited and the term is no longer used, see Agape International Spiritual Center, last accessed October 10, 2019, www.AgapeLive.com.
} 
African American leadership, I surmised that this form of African American religious pluralism is not a minor trend; rather it is popular and attractive across racial lines.

\section{$3 \quad$ Non-Academic Religious Texts}

Examining African American religious pluralism required looking beyond academic religious texts. For sources of experiences, I drew from texts created for lay readers-memoirs and motivational literature. The same was true for theory. I used academic religious writings from the classic theories of religious pluralism. I also looked at writing by a younger generation of religious pluralists: Jeanine Hill Fletcher, Michelle Voss Roberts, John Thatamanil, Catherine Cornille and Peter Phan (among others). These thinkers wrestle explicitly with the kind of multiple belonging I discovered in the section on experience; some looking at language of identity and hybridity with others remaining skeptical about the blurred religious boundaries.

I also looked to anthropology because the term "syncretism" so readily arises in connection with non-Western religious traditions. While as closely connected to theories of religious pluralism as the field of missiology, anthropology more explicitly factors culture into religious practice, and gives less consideration to theological claims or inconsistencies. Finally I looked at books written for more popular audiences, such as Gloria Anzaldua's Borderlands/La Frontera and Gloria Akasha Hull's Soul Talk: the New Spirituality of African American Women. (This was, admittedly, a heavy reading load, but I felt it was necessary to grasp the issues at play.) Drawing from mass-market texts also reminds one that wisdom concerning African American religious pluralism may be found among those who make no attempt to theorize about religious truth claims. Rather, the serious consideration of gender, migration and contemporary spirituality offered by these authors may offer models for African American religious practices that are deeply shaped by migration, indigeneity and plurality.

\section{$4 \quad$ Relevance for All Students}

As a pedagogue, I did not want students to encounter African American religious pluralism as merely an academic exercise. I wanted students to have a personal connection to the material. Los Angeles offers a fertile ground of religious diversity, with worshipping communities representing nearly any religious tradition I choose to teach. Claremont School of Theology, on the other 
hand, has a distinctive cultural composition. At the time of instruction, fewer than 5 percent of matriculating students were African American, and 40 percent of the student body were international students with English as a second language and no assumed knowledge of American history. I had to use cultural experience to make this course relevant for students who were not African American. Thus I taught African American history alongside theories of pluralism. I also asked students to write case studies about their own experiences with religious plurality. Students then had to note the larger issues of religious pluralism at play in their concrete experiences. They shared these reflections at the beginning of each class and thought aloud with their classmates about how religious pluralism operated in their lives.

The final papers were most revelatory, in that all students had the opportunity to write about African American religious pluralism in terms of their own research interests. One African American student wrote about the complexity of religion and culture as an openly gay black Christian navigating a LGBTQIwelcoming secular world of the arts (which functioned for him as religious space) and a more homophobic black Protestantism. A white Mennonite student wrote about how African American religious plurality models a way for Mennonites to wrestle with the cultural plurality in peace traditions and the religious implications of such plurality. A white Buddhist student wrote about how Jan Willis' narrative and Jataka tales offer an engaged religious pluralism that is different from the ways academicians (e.g., John B. Cobb and Masao Abe) discuss the interaction between Christianity and Buddhism. A white Jewish student, motivated by the common calls for justice among the black religious experiences we studied, asked whether religious pluralism can rightly hold social justice ends without making normative theological claims.

I was both surprised and impressed by this pedagogical experience. As the practitioners described their experiences, I heard ideas on religious pluralism that were nowhere in the literature. Likewise, listening to practitioners and searching for appropriate texts showed me that non-Christian African Americans were often straddling and merging religious difference in ways that seemed easy and natural to them, even if misunderstood by church authorities and academic theoreticians. To teach African American religious pluralism required teaching multiple religious belonging and transreligious spirituality.

In a second course, nearly five years later, I returned to teaching African American religious plurality. This time I taught a course entitled: "African American Diasporic Religions." Intentionally interreligious and transnational in scope, I focused on four religions in great depth. I wrote the course description with the idea that the actual religions could change with each round of instruction: 
This course will acquaint students with African-American religions practiced in the United States and throughout the African Diaspora. This class will discuss the historical trajectories, beliefs (theology), cultural and political influences, and contemporary challenges at work in each religious tradition. This course gives attention to both published scholarship and lived experience. The class involves four required field trips in the Los Angeles area (usually on Sundays). The class will focus on four religions each semester. Fall 2015: Black Mega-church, African American New Thought religion, Rastafari and Traditional Yoruba Religion (Ifa)

I use the term "Diasporic" to connote that persons of African descent in various places around the world adhere to the selected traditions. My naming of "diasporic" intentionally subverts canonical notions of "world religions." In the history of theologies of religious pluralism, African diasporic religions have been dismissed out of hand and excised from the conversation of more "evolved" religious traditions. In 1954, Ernst Troeltsch describes these traditions as "heathen" and "animist": "We shall not assume [the earlier proposition of religious pluralism] among the less developed races, where many religious cults are followed side by side, nor in the simple animism of heathen tribes, which is so monotonous in spite of its many variations. ${ }^{17}$ Thirty-five years later, John Hick refers to "preliterate forms of archaic religion" that exist in "parts of Africa, the Americans, Indonesia, Australasia and the Pacific Islands ... [wherein] the local gods and spirits, sometimes ancestors, sometimes totem animals, who are to be variously worshipped, placated or subtly negotiated with."18 In Hick's assessment, these "pre-axial religions" have pedagogical value but lack hope and future vision, and thus are not considered in his theorizing of religious plurality. ${ }^{19}$ Troelstch, Hick and others maintain these positions by their own misunderstanding and lack of understanding of African Diasporic religions and their white colonial supremacist assumptions about them. My grouping of African diasporic traditions insists that these black religions practiced both locally and globally are "world religions." They should be included along with the five classics birthed from

17 Ernst Troeltsch, "The Place of Christianity Among the World Religions," in Attitudes Towards Other Religions: Some Christian Interpretations, ed. Owen C. Thomas (New York, Harper \& Row, 1954, 1969), 8.

18 John Hick, An Interpretation of Religion: Human Responses to the Transcendent (New Haven, CT: Yale University Press, 1989), 22.

19 Hick, 28. 
Orientalism-Islam, Christianity, Judaism, Buddhism and Hinduism. ${ }^{20}$ When African diasporic religions are considered world religions, scholars are forced to think differently about what constitutes a religion, and how and why it is practiced in various locales, and how religions encounter and respond to each other.

\section{$5 \quad$ Religious Experience Anew}

As in the previous course, I incorporated religious experience. Rather than focus on memoir, this class encountered religious experiences in devotional literature and site visits. For every religion, I assigned a book that practitioners read for their own spiritual development: Michael Beckwith's Spiritual Liberation, Fa'lokun Fatunmbi's Iwa-Pele: Ifa Quest ${ }^{21}$ Kenneth Ulmer's Knowing God's Voice, ${ }^{22}$ and Empress Yuajah's Rasta Way of Life: Rastafari Livity. ${ }^{23}$ Students compared and contrasted these readings with their academic readings on the religion connected to the site visit, and their subsequent worship experience there.

Establishing site visits was much more challenging in this course. Given RastafarI and Ifa are traditionally oppressed traditions, one struggles to find locations and meeting times from an internet search. RastafarI only worship around festival days, most of which occur during the summer months outside the academic calendar. As an example of the steps I took to arrange a site visit, I went to a Jamaican restaurant in an area where I heard there was a RastafarI bookstore. I asked the servers in the restaurant, who sent me two doors down to a bookstore that was closed. The owner came out and told me to go to the black arts district (another part of Los Angeles) at night. I went to that district another night and found some people rehearsing on African drums in a small building with an open door. I recognized one of the drummers from a previous personal interaction and asked about the RastafarI community. This drummer took me across the street to the House of Melchizedek, a minority sect of the RastafarI community. Their leader then took me down a dark alley, through the back gate to the recreation room in the home of the leader of the First Church of Rasta. This leader gave me newspapers and told me that the First Church of

\footnotetext{
20 Hick, 33.

21 Awo Fa'lokun Fatunmbi, Iwa-Pele: Ifa Quest: The Search for the Source of Santeria and Lucumi. (Brooklyn, NY: Original Publications, 1991).

22 Kenneth C. Ulmer, Knowing God's Voice: Learning How to Hear God Above the Chaos of Life and Respond Passionately in Faith (Ventura, CA: Chosen Books: 2011).

23 Empress Yuajah, Rasta Way of Life: Rastafari Livity Book (CreateSpace: 2014).
} 
Rasta had lost their building in the neighborhood where I first looked. Now, when there is no large festival, they host a weekly reggae night with a spiritual message at the House of Melchizedek. Although I am not RastafarI, the fact that I wore my hair in dreadlocks and dress in a way appropriate to RastafarI women helped me gain entrée into a community for the site visit. Gaining experiential communal knowledge of African American religions often requires time, tenacity, acculturation and near-insider status. Information about historically oppressed religions (within an historically oppressed race and culture) often travels by word of mouth from those who know where and how to seek such information. With each site visit, I instructed students on appropriate attire - which was quite different for each religious tradition and varied by traditional gender categories. Although we were clearly visitors, we demonstrated respect both by our knowledge and our physical presentation.

Site visits rely upon both the religious diversity and black population of the geographical area. Teaching this course would be possible in most major cities in the United States and African Diaspora where there are significant black populations, but it would look different. For example, the largest African American New Thought communities in Chicago have a history with the Unity Church branch of New Thought, rather than the Religious Science arm of New Thought as do the communities in Los Angeles. Thus African American New Thought communities in Chicago more closely resemble churches in their worship style than the Agape International Spiritual Center. Even within the United States, the history of African Americans and black migrations alter the shape of the worshipping communities. Whether traditional Yoruba practice looks more like Lukumi/Santeria or a contemporary Nigerian practice depends largely on the training and ethnicity of the leader, and the migration patterns of descendants of the U.S. slavery system and of other diasporic blacks. ${ }^{24} \mathrm{Ar}-$ ranging site visits in cities or towns with a smaller black population would be much more difficult. While I was able to find practitioners of Ifa and RastafarI to speak to my students when I taught in Greensboro, NC, there were no nearby worshipping communities of practitioners for a site visit.

24 For example, most African Americans in California have roots in Oklahoma, Louisiana and Texas, where slavery was practiced with different religious and economic patterns than in Georgia and North and South Carolina, from whence many former slaves moved to Washington DC/ Baltimore, New York or Philadelphia. The different immigration patterns of Cubans, Haitians and Nigerians also shape how traditional Yoruba worshipping communities practice. This is just one example of the complexities in local worship experiences. 
This class also correlated experiential knowledge with academic reflection. Exploring African American diasporic religiosity reveals how little academic writing within religious studies covers non-Christian African American religions. Sociologists and political scientists write the best academic texts, covering black mega-churches as a socio-cultural-theological phenomenon. ${ }^{25}$ Students quickly found that in these works, the theological reflection was not as rigorous as that found in the writing of those trained in theology or ethics. Most scholarship on traditional African religions is found in the disciplines of history and anthropology. There is only one scholarly work on African American New Thought churches. We had to look at academic writing on New Thought religions in general-also fairly sparse. Historians and sociologists write most of the books on Rastafarl, ${ }^{26}$ with Noel Erskine's From Garvey to Marley: Rastafari Theology a notable exception. ${ }^{27}$ In other words, studying African American religious diversity requires interdisciplinary study. This is particularly challenging, as each field uses its own distinct language and methodology, and the student must traverse these differences with speed and agility.

In our reading, my students and I found that across religious traditions, African American cultural contexts raise similar issues as points of contention. Issues of liberation and nationalism arise in every tradition, even if resolved quite differently. Each religious tradition wrestles with or takes a clear stance on its relationship to Africa and blackness as a central theme. Each tradition has clear ideas about its role in politics, and how the pursuit of justice is achieved through theology and praxis. Even with these differences, the telos of justice and freedom is a given in each religion. Music and movement are integral to every worship experience, although in vastly different ways. While a survey of African American religious studies will quickly reveal these themes, the Los Angeles context allowed my students to experience them first-hand,

25 Cf. Sandra L. Barnes, Black Megachurch Culture: Models for Education and Empowerment (New York: Peter Lang, 2010); Milmon F. Harrison, Righteous Riches: The Word of Faith Movement in Contemporary African American Religion (New York: Oxford University Press, 2005); and Tamelyn N. Tucker-Worgs, The Black Megachurch: Theology, Gender, and the Politics of Public Engagement (Waco, TX: Baylor University Press, 2012).

26 There are several excellent academic texts on Rastafari religion, with the canonical work being Leonard E. Barrett The Rastafarians 2oth anniv. ed (Boston: Beacon Press, 1977, 1997).

27 Noel C. Erskine, From Garvey to Marley: Rastafari Theology (Tallahassee, FL: University Press of Florida, 2005). 
and as a subject of a lived spirituality with which they could interact, rather than as an object of study.

\section{$7 \quad$ Relevance for All Students}

Again, most of the students in this class were not African American in racial or cultural experience. A first-generation Adventist Chicano student wrote about the roles of women in RastafarI and Zapatista movements_-both nationalist political movements connected to cultural indigeneity. A white doctoral student who usually researches Dharmic traditions wrote about whether the lack of explicit race-consciousness in African American New Thought religion renders it a liberational theology. A Korean-American Protestant student found in the black religious nationalism of traditional Yoruba religion a helpful methodology for helping millennial Korean American Christians find cultural grounding in their faith. A white Muslim convert asked if the spiritual practices found in various African American religious devotional literature might be relevant for humanist spirituality.

Students were able to take what they learned about the particularity of African American religious diversity and apply it to their own research interests. I was delighted with their embrace of religious and cultural nationalism as they used African American religious plurality as the measure for other investigations. This academic activity undermines classical Western training by foregrounding what is usually on the margins.

This pedagogical experiment brought me to three conclusions about African American pluralism. First, African American religious plurality is relevant to all students of religion. Too often, the study of black religions or even black church traditions is seen as an educational praxis for black students alone. While black students may feel a particular cultural connection to learning about African American and African Diasporic religions, they are not the sole beneficiaries of this content. Theological educators are comfortable teaching ancient and Western Christianity to students of color. I adopted that same premise in teaching black religions to every interested student. Learning about African American religious plurality is as important as learning about any other kind of religious plurality, because the people and communities students encounter may believe differently from the way they do, and there are diverse ways of believing within the communities students encounter. Students cannot rely on what William D. Hart calls the standard narrative of black religionan assumption that all African Americans adhere to a black Protestant Christianity making "the black Protestant Church ... virtually conterminous with 
Black Religion" and thereby implying "every other form of black religious expression is normatively peripheral and culturally suspect." ${ }^{28}$ One cannot assume that racial and cultural identity as "black" or African American connotes knowledge of African American history and culture. Thus I included appropriate background information with instruction on each black religious tradition for non-black students, as I would for black students. As a corollary, the ways that African Americans live with religious plurality served as models for nonAfrican American students to think about religiously-plural practices in nonAfrican American contexts also. Through their papers, I repeatedly saw how students harnessed the methodologies of African American religious plurality and applied them in more familiar contexts. These are not acts of cultural appropriation; rather students found language and strategies within African Americans religions that better articulated and named experiences and ideas with which they were wrestling.

Second, African American religious pluralism broadens the intellectual enterprise of religious pluralism. I engaged with religious traditions that are often seen as localized and "animist" rather than global and complex. Most institutions of theological education do not teach a plurality of African American religions or the kind of religious pluralism that emerges from African American religious diversity. Then again, most discussions of world religions do not include African American religious diversity. "New religions" and "indigenous religions" fall into different categories from the five that emerge from Orientalist constructions of the world. The significantly different traditions in those rubrics — new and indigenous - are rarely taught in their individual specificity. I want to remind the larger field of the study of world religion and religious pluralism that a narrower scope is just that - a narrow scope-and that theorists of religious pluralism are obligated to consider religious traditions that, historically, have been rendered invisible in traditional studies of religion. If they were to do so, there would be more religion scholars (my former students among them, perhaps) writing and teaching about African American religious diversity using some of the theological and ethical insights of the broader field. Just as saliently, African American religious pluralism broadens the sources for religious pluralism by pushing the conversation into memoirs, devotional literature, lived experience, motivational, and mass-market literature. The oral testimony of practitioners may be a better source for information about theology and practice than written texts.

28 William David Hart, Black Religion: Malcolm x, Julius Lester, and Jan Willis (New York: Palgrave Macmillan, 2008), 8. 
African American religious scholars generally recognize the plurality of black religious practice, and several scholars engage in a kind of comparative analysis to construct a theology that draws also on non-Christian black religions. ${ }^{29}$ Yet these conversations happen in isolation from those whose work is more explicitly categorized as "theories of religious pluralism." Perhaps, like me, other scholars assume African American religious diversity and sources without considering the need to ask the classic questions about salvation. Perhaps the impulse of liberation theologians to define salvation as survival, liberation and justice in the temporal world has erased the need for most truth claims and confessional statements about Jesus. The wider field of religious pluralism (and comparative theology) can learn from ways black religious scholars embrace and call on black religious plurality in their theological and ethical work.

Third, African American religious pluralism reconstructs the primary questions of theories of religious pluralism. I learned two ground-breaking concepts from my initial inklings, the texts that I taught, the sites we visited and the practitioners who spoke. African American religious pluralism is not just about theological truth claims. African American religious pluralism is about theology and culture, identity, and a sense of community and empowerment. Examining theological differences alone does not get at the heart of why African Americans convert to or remain in religious communities, nor the ease or struggle with which African Americans interact with individuals across religious difference. African American religious pluralism is as much about how individuals and communities merge and straddle religious differences as it is about how people encounter and interact with one another across religious difference. African American religious pluralism involves wrestling with multiple religious belonging and transreligious spirituality as core theoretical questions, rather than as an ancillary or invalid activity in which only a minority engages.

29 Cf. Noel Erskine's Rastafari Theology mentioned earlier, Josiah U. Young's Pan African Theology: Providence and the Legacies of the Ancestors, Will Coleman's Tribal Talk: Black Theology, Hermeneutics and African/ American Ways of "Telling the Story," my work Making a Way Out of No Way: a Womanist Theology and Jawanza Clark's Indigenous Black Theology: Toward an African Centered Theology of the African-American Religious Experience do this in explicit ways. Several other black religious scholars draw on conjuring and folk religion too-Yvonne Chireau's Black Magic: Religion and the African American Conjuring Tradition, Katie Cannon's Black Womanist Ethics, etc. One could even count James Cone's use of spirituals in The Spirituals and the Blues: an Interpretation and Dwight Hopkins's use of slave narratives in Shoes that Fit Our Feet: Sources for a Constructive Black Theology under this rubric. This list doesn't even include the ways African theologians engage with religious pluralism in their liberation theologies. 
African American religious pluralism thus disrupts theories of religious pluralism at large. Relevant for all students and scholars, African American religious pluralism expands the content and sources of the field, and reframes the central questions of the religious pluralism enterprise.

\section{Bibliography}

Albanese, Catherine. America: Religions and Religion. Belmont, CA: Wadsworth, 2006. Ammerman, Nancy T. Everyday Religion: Observing Modern Religious Lives. New York: Oxford University Press, 2007.

Anonymous. Letter to the Editor. Essence (November 2000).

Barnes, Sandra L. Black Megachurch Culture: Models for Education and Empowerment. New York: Peter Lang, 2010.

Barrett, Leonard E. The Rastafarians, 2oth Anniversary ed. Boston: Beacon Press: 1997. Beckwith, Michael Bernard. Spiritual Liberation: Fulfilling Your Soul's Potential. New York: Atria Books, 2009.

Cannon, Katie Black Womanist Ethics. Eugene, OR: Wipf and Stock, 2006.

Chireau, Yvonne. Black Magic: Religion and the African American Conjuring Tradition. Berkeley, CA: University of California Press, 2003.

Clark, Jawanza. Indigenous Black Theology: Toward an African Centered Theology of the African-American Religious Experience. New York: Palgrave Macmillan, 2012.

Cobb, John B. Beyond Dialogue: Toward a Mutual Transformation of Christianity and Buddhism. Eugene, OR: Wipf and Stock, 1998.

Coleman, Monica. Making a Way Out of No Way: a Womanist Theology. Minneapolis, MN: Fortress Press: 2008.

Coleman, Will. Tribal Talk: Black Theology, Hermeneutics and African/American Ways of "Telling the Story." University Park, PA: The Pennsylvania State University Press, 2000.

Cone, James. The Spirituals and the Blues: An Interpretation. New York: Orbis, 1992.

Erskine, Noel C. From Garvey to Marley: Rastafari Theology. Tallahassee, FL: University Press of Florida, 2005.

Fa'lokun Fatunmbi, Awo. Iwa-Pele: Ifa Quest: The Search for the Source of Santeria and Lucumi. Brooklyn, NY: Original Publications, 1991.

Frazier, E. Franklin. Negro Church in America, 1963. New York: Schocken, 1974.

Griffin, David Ray, ed. Deep Religious Pluralism. Louisville, KY: Westminster John Knox, 2005 .

Hall, Edward T. The Silent Language, 1959. New York: Anchor Books, 1973.

Harrison, Milmon F. Righteous Riches: The Word of Faith Movement in Contemporary African American Religion. New York: Oxford University Press, 2005. 
Hart, William David. Black Religion: Malcolm X, Julius Lester, and Jan Willis. New York: Palgrave Macmillan, 2008.

Herskovkits, Melville K. Myth of a Negro Past, 1941. Boston: Beacon Press, 1990.

Hick, John. An Interpretation of Religion: Human Responses to the Transcendent. New Haven, CT: Yale University Press, 1989.

Hopkins, Dwight. Shoes that Fit Our Feet: Sources for a Constructive Black Theology. New York: Orbis, 1993.

Hucks, Tracey E. Yoruba Traditions and African American Religious Nationalism. Albuquerque, NM: University of New Mexico Press: 2014.

Johnson, Deborah L. The Sacred Yes: Letters from the Infinite. Boulder, CO: Sounds True, 2006.

"Let Us Break Bread," African American Spiritual. First published The Journal of American Folklore and Saint Helena Island Spirituals (1925).

Lincoln, C. Eric and Lawrence H. Mamiya. The Church in African American Experience Durham, NC: Duke University Press, 1990.

McGuire, Meredith B. Lived Religion: Faith and Practice in Everyday Life. New York: Oxford University Press, 2008.

Pinn, Anthony B. "Ashe! Santeria, Orisha-Voodoo and Oyotunji Village." In Varieties of African American Religious Experience, 59-114. Minneapolis, MN: Fortress, 1998.

Raboteau, Albert J. Slave Religion: The "Invisible Institution" in the Antebellum South. New York, Oxford University Press, 1978.

Troeltsch, Ernst. "The Place of Christianity Among the World Religions." In Attitudes Towards Other Religions: Some Christian Interpretations, edited by Owen C. Thomas, 73-91. New York, Harper \& Row, 1954, 1969.

Tucker-Worgs, Tamelyn N. The Black Megachurch: Theology, Gender, and the Politics of Public Engagement. Waco, TX: Baylor University Press, 2012.

Turner, Richard Brent. "African Muslim Slaves and Islam in Antebellum America." The Cambridge Companion to American Islam, edited by Juliane Hammer and Omid Safi, 28-44. New York: Cambridge University Press, 2013.

Ulmer, Kenneth C. Knowing God's Voice: Learning How to Hear God Above the Chaos of Life and Respond Passionately in Faith. Ventura, CA: Chosen Books: 2011.

Vanzant, Iyanla. Tapping the Power Within: A Path to Self-Empowerment for Women (1998). Carlsbad, CA: Hay House: 2009.

Walker, Alice. "The Only Reason You Want to Go to Heaven Is That You Have Been Driven Out of Your Mind (Off Your Land and Out of Your Lover's Arms): Clear Seeing Inherited Religion and Claiming the Pagan Self." In Anything We Love Can Be Saved: A Writer's Activism, 1-28. New York: Ballatine, 1997.

Young, Josiah U. Pan African Theology: Providence and the Legacies of the Ancestors. Trenton, NJ: Africa World Press, 1992.

Yuajah, Empress. Rasta Way of Life: Rastafari Livity Book (CreateSpace: 2014). 